\title{
ANALYSIS OF ALTIMETRIC DATA OBTAINED BY LIDAR IN AN AREA OF ATLANTIC FOREST IN SOUTHEASTERN BRAZIL
}

\section{Análise de dados altimétricos obtidos pelo LiDAR em uma área de floresta Atlântica no sudeste do Brasil}

\author{
Elisa Araujo Penna Caris \\ Pesquisadora Associada do Laboratório Espaço de Sensoriamento Remoto e Estudos Ambientais, \\ Departamento de Geografia, UFRJ \\ elisapcaris@gmail.com \\ Carla Bernadete Madureira Cruz \\ Professora Titular do Departamento de Geografia - UFRJ \\ cmad@gmail.com \\ Bruno Coutinho Kurtz \\ Pesquisador Titular - Jardim Botânico do Rio de Janeiro \\ bkurtz@jbrj.gov.br
}

Artigo enviado para publicação em 01/12/2019 e aceito em 29/04/2020

DOI: $10.12957 /$ tamoios.2020.47023

\begin{abstract}
We evaluated the accuracies of Digital Terrain Models (DTMs) generated from LiDAR data in an area of montane Atlantic Forest in the municipality of Rio de Janeiro, Brazil, and explored the use of those data to estimate tree heights. We employed the interpolation of data on a regular grid and a Triangular Irregular Network (TIN) using two softwares (ArcGis 10.3 and Fusion), with 0.4 and $1 \mathrm{~m}$ pixels, at scales of 1:2,000 and 1:5,000. The DTMs were evaluated using statistical inferences, considering 165 points surveyed using a geodetic Total Station (TS) in a 20x50 m plot. The models were classified according to the standard regulatory instructions of National Cartography technical norms. Accuracy varied from $0.59 \mathrm{~m}$ to $0.63 \mathrm{~m}$ among the specifications use for scales of 1:2,000 and 1:5,000. The maximum tree crown heights encountered with the eight Canopy Height Models (CHMs) employed were very similar to field measurements. When our data were analyzed by height classes, however, differences were encountered between the different softwares and interpolation methods used, indicating the influence of DTMs on tree height estimates based on LiDAR data.
\end{abstract}

Key-words: Laser scanning; Digital Terrain Model; Canopy Height Model; Atlantic Forest; Tijuca National Park.

\section{Resumo}

Este trabalho avaliou a acurácia de Modelos Digitais de Terreno (MDT) gerados a partir de dados LiDAR em trecho de Mata Atlântica de encosta, município do Rio de Janeiro, RJ, e explorou o uso destes dados para a estimativa de altura de árvores. Foram utilizados métodos de interpolação de grade regular e grade irregular triangular em dois softwares, ArcGis 10.3 e Fusion, com pixels de 0,4 e $1 \mathrm{~m}$, para atender às escalas de 1:2.000 e 1:5.000. Os MDT foram avaliados a partir de inferências estatísticas, considerando 165 pontos levantados com Estação Total (ET) numa parcela de 20x50 m. Os modelos foram classificados de acordo com os padrões das instruções reguladoras das normas técnicas da Cartografia Nacional. A acurácia variou de 0,59 m até 0,63 $m$ entre as especificações para as escalas 1:2.000 e 1:5.000. As alturas máximas encontradas nos oito Modelos Digitais de Copa (MDC) ficaram bem próximas àquela medida em campo. No entanto, quando os dados são analisados por classes de altura, são encontradas diferenças entre os softwares e os métodos de interpolação, indicando a influência dos MDT nas estimativas de altura de árvores a partir de dados LiDAR.

Palavras-chave: Escaneamento a laser; Modelo Digital de Terreno, Modelo Digital de Copa; Mata Atlântica; Parque Nacional da Tijuca. 


\section{Introduction}

LiDAR (Light Detection and Ranging) is a Remote-Sensing technology that allows three-dimensional spatial analysis. It is based on the principle of laser beam emission from a platform (aerial, terrestrial or orbital) to the Earth's surface and its reception resulting in a point clouds with $\mathrm{x}, \mathrm{y}$ and $\mathrm{z}$ coordinates having centimeter-level precision. As a result, LiDAR technology has been widely used to produce models of land surfaces and capture elevations on them, producing Digital Terrain Models (DTMs) and Digital Surface Models (DSMs) respectively (BECKER; CENTENO, 2013).

The capacity of LiDAR laser pulses to penetrate dense forest cover makes it a more accurate technology than photogrammetry for generating DTMs under dense vegetation conditions (LIU, 2008). By providing high resolution horizontal and vertical information and vertical accuracy, LiDAR has demonstrated enormous potential for use in ecological research (LIM et al., 2003; BERGEN et al., 2009), such as in the production of Canopy Height Models (CHMs). It must be pointed out, however, that the identification of structural vegetation characteristics from LiDAR data is greatly influenced by variables such as point data density, requiring that the models produced are calibrated and validated by field data to produce truly accurate estimates. That requirement becomes more challenging in tropical environments due to the complexity of their forest structures and the high spatial and temporal variability of vegetation density (LEITOLD et al., 2016).

While the high resolution obtainable with LiDAR allows the acquisition of more precise data about the Earth's surface, that technology must be complemented with additional studies examining the quality of the vertical data (CRUZ et al., 2011). Reutebuch et al. (2003) discussed the importance of evaluating LiDAR accuracy in forest environments and analyzed the accuracy of a DTM generated in a 500 ha mountainous area using 347 control points (in open areas as well as in sites with dense forest cover in a conifer forest in Washington State, USA). The mean error of the DTM under those conditions was found to be $0.22 \pm 0.24 \mathrm{~m}$, with elevational differences varying from -0.63 to $1.31 \mathrm{~m}$, with the greatest errors occurred in areas with tree cover $(0.31 \mathrm{~m})$. Clark et al. (2004) analyzed the accuracy of DTM generated by LiDAR in a dense forest in Costa Rica. Their results indicated a RMSE (Root Mean Square Error) of $2.29 \mathrm{~m}$ as compared to 3859 points taken in the field by a geodetic Total Station using a Differential Global Positioning System (DGPS). In the oldest forest areas, the RMSE on steep slopes was $0.67 \mathrm{~m}$, a value greater than the error on more level surfaces.

Schimallesky and Centeno (2007) evaluated the quality of altimetry information derived from LiDAR in a fragment of Mixed Ombrophilous Forest in Paraná State, Brazil, and detected the presence of trees forming a sub-canopy layer that strongly reduced the penetration rate of the laser pulses to ground level. Their results indicated that the dense layer of vegetation interfered with the penetration rates of the laser pulses, introducing errors in the interpolation processes of the DTM due to the low densities of points reaching groundlevel and the consequent irregular distribution of those points.

Very few projects using LiDAR have been undertaken in the Atlantic Forest due to its topographically irregular environments and wide altitudinal gradients along the Brazilian coast. Leitold et al. (2016) compared the DTMs generated from LiDAR data with different point densities per $\mathrm{m}^{2}$ in a mountainous region of the Serra do Mar Range in São Paulo State, and reported a small super-estimation in their model that increased with lower point densities. Barros et al. (2013) evaluated the accuracy of a DTM generated by LiDAR in an area of dense vegetation in the municipalities of São Sebastião and Caraguatatuba (São Paulo State), 
analyzing the errors according to Cartographic Accuracy Standards (CAS) and testing hypotheses to evaluate the precision of the resulting products. According to those authors, although the results did not fully realize initial expectations, they were considered very good, and probably represented the best DTM results for dense vegetation cover.

In 2012, the Mayor's Office of the city of Rio de Janeiro acquired an aerial LiDAR survey of the Tijuca Massif, with a mean density of $10 \mathrm{pts} / \mathrm{m}^{2}$. The Tijuca Massif is in the eastern portion of the city and it is largely covered by montane forest vegetation (DIAS; COELHO NETTO, 2011). That survey was designed (in part) to prepare a risk analysis of landslides on the mountain slopes.

Considering the irregular topography of the Tijuca Massif, it is essential to examine the vertical accuracy of the elevation models generated from LiDAR data so that they can be used in ecological studies. Within that context, the present work sought to analyze the accuracy of the DTMs derived from LiDAR data in "Sector A" in the Tijuca National Park (with dense forest cover). Therefore, this work specially addresses two main aims:

(1) Evaluate the accuracy of DTMs using different interpolation techniques at different scales, comparing the results with control points that were acquired using a geodetic Total Station, allowing statistical investigations of errors;

(2) Generate CHMs using different interpolation techniques and compare them to the tree height data measured during field work, in order to check the potential use of these data in ecological research.

\section{Materials and Methods}

Study area

The study area was located in "Sector A" of the Tijuca National Park (TNP). The TNP is situated on the Tijuca Massif and covers an area of 3953 ha. The park is subdivided into four sectors (Floresta da Tijuca, Serra da Carioca, Pedra Bonita/Pedra da Gávea, and Pretos Forros/Covanca - Figure 1) that differ according to their use and human occupation, environmental characteristics and states of conservation (ICMBio, 2008). The vegetation cover in the National Park is classified as Dense Montane and Sub-Montane Ombrophilous Forest (ICMBio, 2008; IBGE, 2012) and, according to Coelho Netto et al. (2007), approximately $35 \%$ of the area of Tijuca Massif is covered by late secondary or local climax forest.

In terms of its geomorphology, the TNP demonstrates a mountainous landscape with elevations between 80 and $1023 \mathrm{~m}$ a.s.l. The landscape is generally oriented in a northeastsouthwest direction and, according to Oliveira et al. (1995), that orientation is reflected in the environmental and vegetation characteristics of its slopes. While the slopes facing the north demonstrate more extreme climatic variations, the closed canopies of the forested slopes having southern exposures retain more heat and humidity and do not demonstrate temperature extremes. The local climate is classified as tropical altitudinal (COELHO NETTO, 1985). 


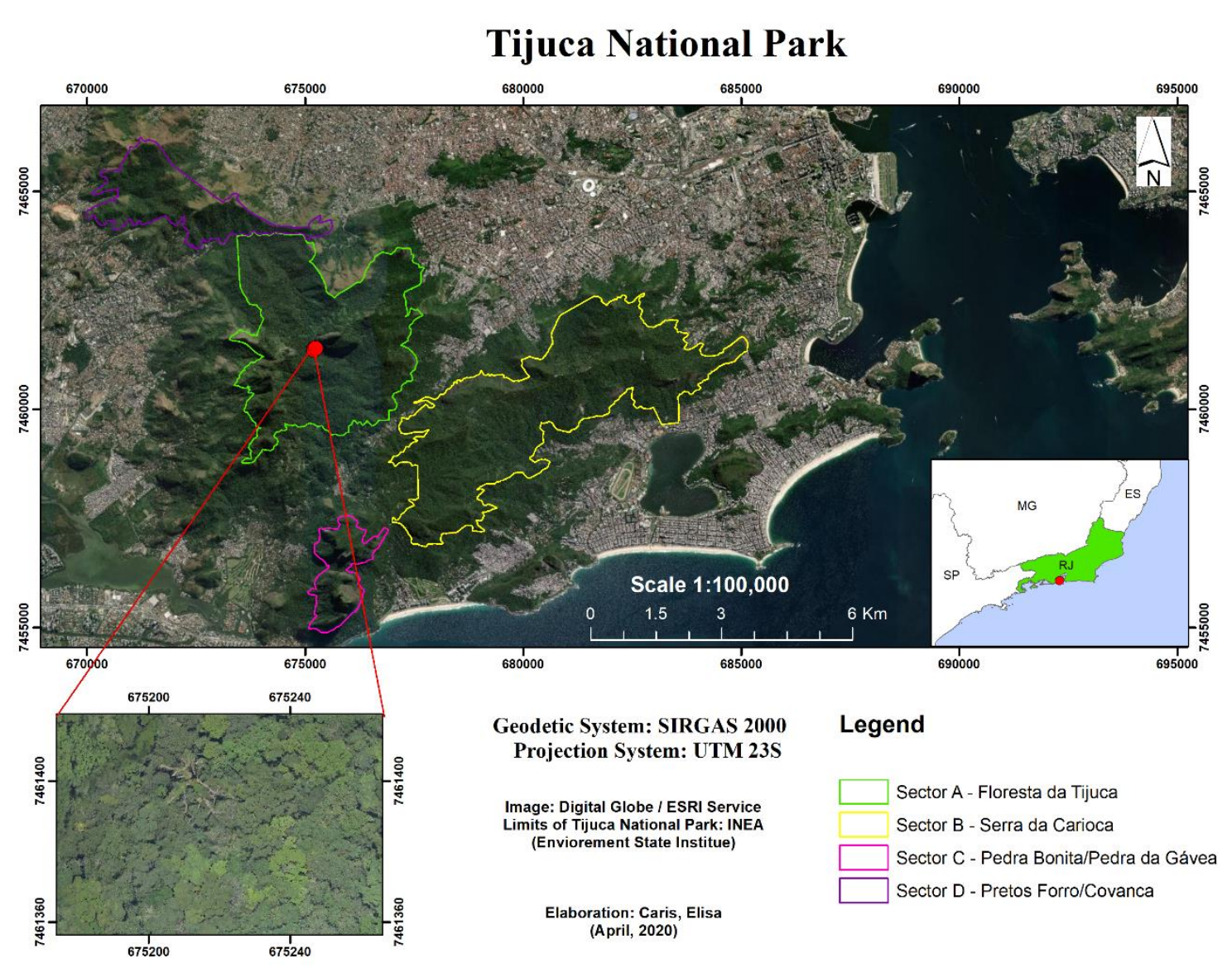

Figure 1: Locations of the four sectors of the Tijuca National Park, Rio de Janeiro State, Brazil. Note the dense forest cover of Sector "A".

\section{Methodology}

\section{LiDAR data}

The LiDAR data used here was obtained from an aerial survey undertaken on November 6, 2012, for the Geotechnical Institute Foundation of the municipality of Rio de Janeiro (GEORIO). The sensor was transported by helicopter and covered $155 \mathrm{~km}^{2}$ of the Tijuca Mountain. Table 1 presents the parameters and specifications of the aerial survey data gathered by the HANSA- Geofísica e Aerolevantamento Ltda. company. 
Table 1: Data from the aerial survey of the Tijuca Massif undertaken by the HANSA Geofísica e Aerolevantamento Ltda. company, acquired for the Mayor's Office of the city of Rio de Janeiro, Brazil.

\begin{tabular}{|c|c|}
\hline Parameters & Specifications \\
\hline Equipment & Sensor RIEGEL LMS-Q560-HB50 Np for 4 to $5 \mathrm{pt} / \mathrm{m}^{2}$ \\
\hline Projection diameter of the laser beam & $<30 \mathrm{~cm}$ \\
\hline Sweeping angle - FOV / 2-Nadir & $\pm 15^{\circ}$ \\
\hline $\begin{array}{l}\text { IMU - Aerocsntrol-IID by the IGI - Ingenieut-Gesell } \\
\text { Schaft-Fur Interfaces MBH company using fiber optic } \\
\text { gyroscope technology (FOG) }\end{array}$ & $\begin{array}{l}\text { Position within } 0.1 \mathrm{~m} \text {; velocity } 0.005 \mathrm{~m} / \mathrm{s} \text {; roll-pitch } \\
0.004^{\circ} \text {; heading } 0.01^{\circ}-256 \mathrm{HZ}\end{array}$ \\
\hline Repetition rate of the laser pulse & $150 \mathrm{khz}$ prr \\
\hline Pulse density $/ \mathrm{m}^{2}$ & 4 to 5 \\
\hline Flight altitude & 1,200 feet $A G L$ \\
\hline Aircraft speed C182 & $90 \mathrm{KTN}$ \\
\hline Overlap Swath - laser acquisition & $53.4 \%$ \\
\hline
\end{tabular}

The point cloud was classified using TerraScan software by the same company that performed the survey; Sector "A" of the TNP comprises 25 archives of Lidar Data Exchange Format File (.las), UTM23S/SAD69, totaling 270 million points. The .las archives classify points following the ASPRS (American Society for Photogrammetry and Remote Sensing) orientation. The mean density of points in Sector "A" was $8.78 \mathrm{pt} / \mathrm{m}^{2}$.

\section{Digital Terrain Models}

The DTMs based on LiDAR data were elaborated for the entire area of Sector "A" (25 archives). Due to the sizes of the archives, it was necessary to process some of them separately and subsequently generate a mosaic of the area. That mosaic was assembled using ArcGis 10.3 software using the mosaic to new raster tool.

We used two values for the pixel size $(0.4$ and 1$)$ to evaluate the qualities of the products generated to create cartographic scales of 1:2,000 and 1:5,000. Only points classified as ground were interpolated for the DTMs. The DTMs in raster format were generated using two different softwares: FUSION (free software) and ArcGis 10.3, using distinct methodologies.

In ArcGis 10.3, the methodology employed regular cells and is called Binning. Due to the high point density, the same cell can often contain two or more points and its stipulated value is critical to the Cell Assignment Type. The Cell Assignment Type criteria used was the parameter "Average", as suggested by Barbosa (2015), where the mean value of all of the points in the cell is attributed to it. For the DTMs based on the triangulation methodology (TIN - Triangular Irregular Network), interpolation was performed using only the nearest neighbor (Natural Neighbor).

There are two commands for creating a DTM when using Fusion software: GridSurfaceCreate and TINSurfaceCreate. Additional parameters, however, can be used in each of those commands, such as surface smoothing (MCGAUGHEY, 2016), although no additional optional parameter was used in the present work. The DTMs were generated based 
on a line of command, altering only pixel size. In the methodology of GridSurfaceCreate, the area is divided into a regular grid based on dimensions defined by the user. The elevations of the cells are determined by the mean elevation of its points. The values of the cells without points are determined by the Natural Neighbor interpolation method. The TINSurfaceCreate method initially generates a Triangular Irregular Network (TIN) based on the point cloud; the surface, in the form of a grid, is then interpolated based on that irregular web (the triangular algorithms used were developed by J.R. Shewechuk of the University of California [MCGAUGHEY, 2016]).

A total of eight models were produced, four for each of the stipulated pixel sizes. As the survey was performed using SAD69 datum, it was necessary to transform the coordinates of the geodesic reference system to that currently used in Brazil (SIRGAS 2000), which was done based on the transformation parameters between geodesic systems as defined by IBGE (Brazilian Institute of Geography and Statistics). That processing was performed using ArcGis 10.3 software according to IBGE (2015).

Altimetric precision was evaluated for each of the eight models generated. Those analyses used 165 points defined by the Total Station (TS) in a 20x50 m plot located on a southern facing slope with a mean declivity of $25.45^{\circ}$. The base of that plot was at an elevation of $656 \mathrm{~m}$, ending at $678 \mathrm{~m}$. The TS survey required the initial establishment of two points using a GNSS (Global Navigation Satellite System) apparatus, which were postprocessed at the site by IBGE. The 165 points in the plot were then collected using a Geodetic G2 Total Station within a closed polygon. The data were processed using the Geooffice function. The field data were collected between February and March/2018 in Sector "A" of the TNP.

The extraction of altimetric data from the DTMs was performed using the Extract Value to Multi Points function of ArcGis 10.3. We calculated the differences between the elevations obtained from the DTMs and the values determined in the field. The final evaluation of the results was based on three approaches. The first approach consistent of evaluation based on the limits established by the Cartographic Accuracy Standard (CAS) according to Brazilian Law $n^{\circ} 89.817$ (BRASIL, 1984), in which at least $90 \%$ of the points evaluated must demonstrate differences within the tolerances defined for each map scale; the total standard deviations of all of the points analyzed must be less than the established tolerance limits to guarantee that the points that do happen to exceed the defined tolerance are not excessively distant from it. As the CAS refers only to tolerances related to equidistances, we chose to use as references the equidistance values most typical of each scale, as presented in Table 2. 
Table 2: Limits established by the Cartographic Standard of Accuracy (CAS). Adapted from Barros et al. (2013). The Mean Square Error (MSE) is to be understood as the Error or Standard Error.

\begin{tabular}{|l|l|l|l|l|l|l|}
\hline \multicolumn{3}{|c|}{ CAS } & \multicolumn{2}{c|}{$1: 2.000$ Eq. 1m } & \multicolumn{2}{c|}{$1: 5.000$ Eq. 2m } \\
\hline & Tol. (Eq.) & EMQ (Eq.) & Tol. (Eq.) & EMQ (Eq.) & Tol. (Eq.) & EMQ (Eq.) \\
\hline Classe A & $1 / 2$ & $1 / 3$ & 0,5 & 0,33 & 1,0 & 0,66 \\
\hline Classe B & $3 / 5$ & $2 / 5$ & 0,6 & 0,4 & 1,2 & 0,8 \\
\hline Classe C & $3 / 4$ & $1 / 2$ & 0,75 & 0,5 & 1,5 & 1,0 \\
\hline
\end{tabular}

The data were also evaluated following the methodology proposed by Santos et al. (2016), using GEOPEC software and spatial statistics for bias analysis. Evaluations of cartographic products are made using Technical Specifications to Vectorial Geospatial Data Acquisition (ET-ADGV), a document linked to National Spatial Data Infrastructure (NSDI), which can be allied to Brazilian Law $\mathrm{n}^{\circ} 89.817$ - allowing a more rigorous evaluation of digital cartographic products (Annex 2.4, of the Technical Specifications of Geospatial Data Acquisition).

Altimetric precision was also evaluated using statistical inferences, following Vieira and Genro (2013). According to those authors and based on an adaptation by Congalton and Green (2009), the methodology estimates accuracy independent of the existence of a relevant bias. That methodology considers the use of predefined accuracy patterns based on the maximum probable error in relation to confidence intervals. The statistical foundations applied are all based on the PEC, considering a $90 \%$ probability for the different classes with the t-Student distribution as the statistical inference, emphasizing that the accuracy values are overwhelmingly dependent on the sampling method.

\section{Digital Height Models and Vegetation Surveys}

To evaluate the quality of the DTMs and its influence on the estimates of tree heights, we generated CHMs based on the differences between the DSMs and DTMs (Figure 2). The DSMs were generated using the same software but interpolated to generate the DTMs using all of the return signals from the point cloud. Those differences were calculated using ArcGis 10.3 and employing the raster calculator tool. It is possible, however, to create a CHM by way of an optional parameter that indicates the DTM using a single Fusion software command (GORGENS et al., 2014). 


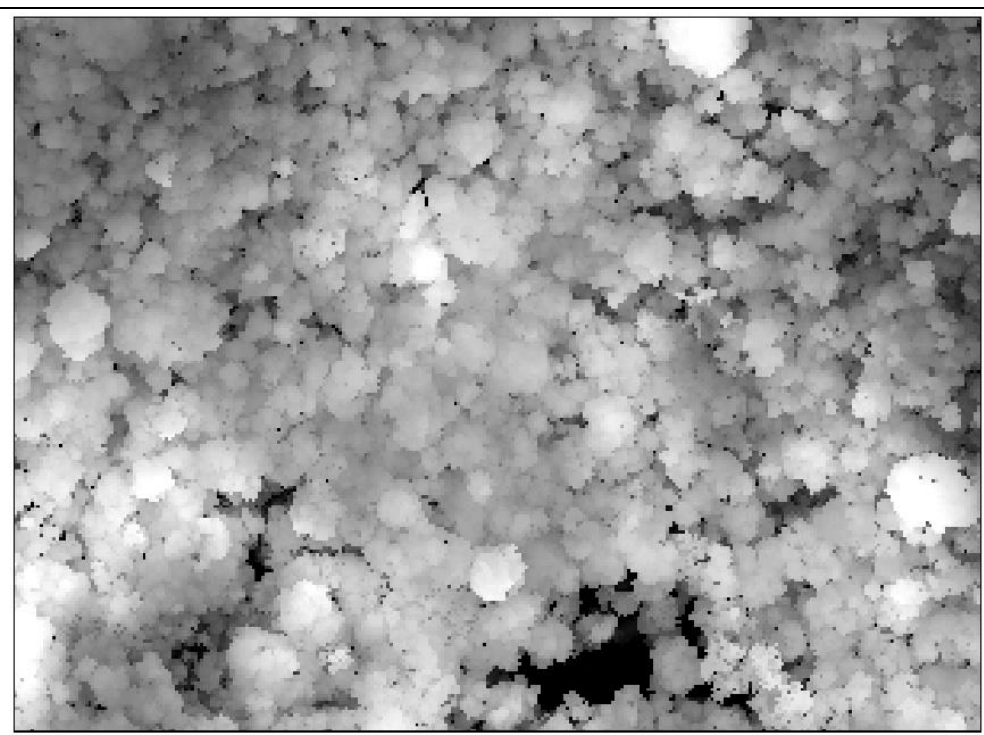

Figure 2: Example of a Canopy Height Model (CHM) generated from the differences between a Digital Surface Model (DSM) and a Digital Terrain Model (DTM), in Sector "A" of the Tijuca National Park, RJ, Brazil.

A vegetation survey was undertaken in the same plot used for the TS survey (between 2016 and 2017) to compare with the CHMs, recording all of the shrub-arboreal individuals with diameters $\geq 5 \mathrm{~cm}$ at 1.30 above ground level, and minimum heights of $1.30 \mathrm{~m}$. The total heights of all individuals were estimated by a field assistant with significant experience in that activity.

\section{Results and Discussion}

To facilitate the reader, abbreviations will be used for each of the models generated: DTMFt (models generated using Fusion software and the TINSurfaceCreate command); DTMFg (models generated using Fusion software and the GridSurfaceCreate command); DTMAb (models generated using ArcGis 10.3 software and the Binning command; and DTMAt (models generated using ArcGis 10.3 software and the TIN command).

When all of Sector "A" in the TNP was analyzed for the maximum and minimum altitudes of the DTMs by all of the models and considering the different pixel values $(0.4$ and $1 \mathrm{~m}$ ), we could perceive small variations in elevations. The minimum heights varied from $85.87 \mathrm{~m}$ using DTMFg with $1 \mathrm{~m}$ pixels, to $86.01 \mathrm{~m}$ using DTMAt, also with $1 \mathrm{~m}$ pixels. The maximum landscape elevations varied between $1021.16 \mathrm{~m}$ using DTMfg with $0.4 \mathrm{~m}$ pixels, to $1021.09 \mathrm{~m}$ using DTMFg and DTMAb, both with $1 \mathrm{~m}$ pixels. Those small differences are probably related to the interpolation methods used and the predefined pixel sizes.

The analysis of altimetric precision of the DTMs (0.4 m pixels), based on the TS survey, indicated the poorest results from DTMFg among the four methods analyzed (Table 3 ). That product was only classified at the 1:5,000 scale and demonstrated the greatest elevational difference $(2.67 \mathrm{~m})$ when compared to the points determined by the TS, with an estimated precision of $1.53 \mathrm{~m}$ according to the methodology proposed by Vieira and Genro (2013). In the other three models analyzed, the maximum tree height differences varied 
between $0.9 \mathrm{~m}$ in the DTMAt to $0.98 \mathrm{~m}$ in the DTMFt. Those results are very similar and indicate that the interpolation methods used had similar efficiencies.

Table 3: Syntheses of the Digital Terrain Models (DTMs) analyses derived from the LiDAR point clouds with $0.4 \mathrm{~m}$ pixels, based on PEC and the methodology proposed by Santos et al. (2016) and Vieira and Genro (2013), in Sector "A" of the Tijuca National Park, RJ, Brazil. $\Delta \mathrm{H}=$ Difference between the points determined by the Total Station and their homologs (in absolute values).

\begin{tabular}{|c|c|c|c|c|c|c|}
\hline \multirow{2}{*}{$\begin{array}{l}\text { Method } \\
\text { /Software }\end{array}$} & \multicolumn{2}{|c|}{$\begin{array}{c}\text { Decree No. } \\
89.817 / 1984\end{array}$} & \multirow{2}{*}{$\Delta \mathrm{H}$} & \multicolumn{2}{|c|}{$\begin{array}{l}\text { GEOPEC (SANTOS et al. } \\
2016 \text { ) }\end{array}$} & \multirow{2}{*}{$\begin{array}{l}\text { Vieira and } \\
\text { Genro (2013) } \\
\begin{array}{c}\text { Analogous to } \\
\text { PEC }\end{array}\end{array}$} \\
\hline & $90 \%$ & EP & & $\begin{array}{l}\text { PEC-PCD } \\
\text { ET-CQDG }\end{array}$ & $\begin{array}{c}\text { Bias analysis } \\
\mathrm{ttab}=1.65\end{array}$ & \\
\hline \multirow{2}{*}{ DTMFt } & 0.536 & 0.194 & \multirow{2}{*}{$\begin{array}{c}\text { Min } 0.003 \\
\text { Mean: } 0.041 \\
\text { Max: } 0.981\end{array}$} & \multirow[b]{2}{*}{$\begin{array}{l}1: 2,000 \\
\text { Class C }\end{array}$} & \multirow[b]{2}{*}{ t calc $(h)=1.64$} & \multirow{2}{*}{$\begin{array}{c}0.59 \\
1: 2,000 \text { Class B }\end{array}$} \\
\hline & \multicolumn{2}{|c|}{$\begin{array}{l}1: 2,000 \\
\text { Class B }\end{array}$} & & & & \\
\hline \multirow{2}{*}{ DTMFg } & 1.303 & 0.495 & \multirow{2}{*}{$\begin{array}{c}\text { Min } .0 .002 \\
\text { Mean: }-0.164 \\
\text { Max: } 2.67\end{array}$} & \multirow[b]{2}{*}{$\begin{array}{l}1: 5,000 \\
\text { Class D }\end{array}$} & \multirow[b]{2}{*}{$\begin{array}{c}* \mathrm{t} \text { calc }(\mathrm{h})= \\
-2.49\end{array}$} & \multirow{2}{*}{$\begin{array}{c}1.53 \\
1: 5,000 \text { Class C }\end{array}$} \\
\hline & \multicolumn{2}{|c|}{$\begin{array}{l}1: 5,000 \\
\text { Class B }\end{array}$} & & & & \\
\hline \multirow[b]{2}{*}{ DTMAt } & 0.517 & 0.188 & \multirow{2}{*}{$\begin{array}{c}\text { Min :0.004 } \\
\text { Mean: } 0.057 \\
\text { Max:0.89 }\end{array}$} & \multirow[b]{2}{*}{$\begin{array}{l}1: 2,000 \\
\text { Class C }\end{array}$} & \multirow[b]{2}{*}{$\mathrm{t}$ calc $(\mathrm{h})=2.36$} & \multirow{2}{*}{$\begin{array}{c}0.57 \\
1: 2,000 \text { Class B }\end{array}$} \\
\hline & \multicolumn{2}{|c|}{$\begin{array}{l}1: 2,000 \\
\text { Class B } \\
\end{array}$} & & & & \\
\hline \multirow[b]{2}{*}{ DTMAb } & 0.527 & 0.191 & \multirow{2}{*}{$\begin{array}{c}\text { Min : } 0.001 \\
\text { Mean: } 0.061 \\
\text { Max: } 0.9\end{array}$} & \multirow[b]{2}{*}{$\begin{array}{l}1: 2,000 \\
\text { Class C }\end{array}$} & \multirow[b]{2}{*}{$\mathrm{t}$ calc $(\mathrm{h})=2.45$} & \multirow[b]{2}{*}{$\begin{array}{c}0.58 \\
1: 2,000 \text { Class B }\end{array}$} \\
\hline & \multicolumn{2}{|c|}{$\begin{array}{l}1: 2,000 \\
\text { Class B }\end{array}$} & & & & \\
\hline
\end{tabular}

*Non-normal sample. All values in meters.

In terms of accuracy, the best results were obtained with DTMAt $(0.57 \mathrm{~m})$; although that model demonstrated bias. DTMFt and DTMAb demonstrated accuracies of 0.59 and 0.58 $m$ respectively, with DTMAb also demonstrating bias. It could be observed in those cases that the means of the altitudinal differences between those observed in the field and those obtained by DTM were not zero, with values of $-0.164 \mathrm{~m}$ for DTMFg, $0.057 \mathrm{~m}$ for DTMAt, and $0.061 \mathrm{~m}$ for DTMAb.

It was expected that the evaluation based on Santos et al. (2016) would generate the worst results among the different models due to the rigidity innate in ET-CQDG. Except for DTMFg, which agreed with the Class D 1:5,000 scale, the other three models generated agreed with the Class C 1:2,000 scale.

Despite the non-normality of the sample, it was possible to perceive a bias to underestimate elevations in DTMFg, with approximately $60 \%$ of the points analyzed demonstrating height differences less than zero (Figure 3). The analysis of the discrepancy graph of DTMFg clearly shows a bias to underestimate model elevations above $662 \mathrm{~m}$. The other two models that demonstrated bias (DTMAt and DTMAb) demonstrated a general bias of overestimating elevations, in spite of demonstrating an underestimation of elevation beginning at $662 \mathrm{~m}$. As was noted earlier, DTMFt was the only model that did not demonstrate bias and was therefore considered to provide the best result. 


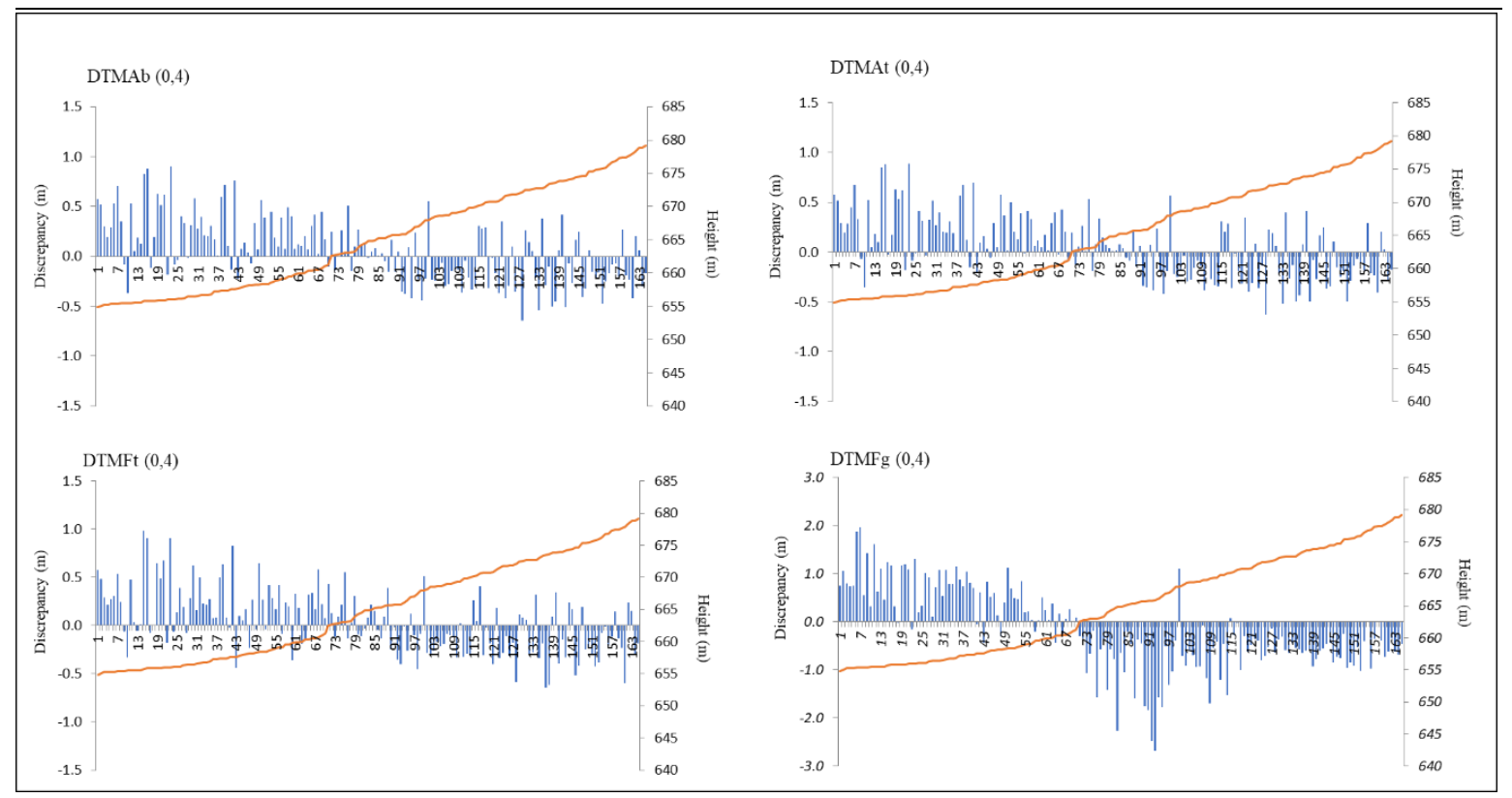

Figure 3: Graphs demonstrating the discrepancies between the points determined by the Total Station and their homologs, considering $0.4 \mathrm{~m}$ pixels. The orange line indicates the topography of the plot in Sector "A" of the Tijuca National Park, RJ, Brazil.

Table 4 presents the results of the altimetric evaluations of the DTMs generated with $1 \mathrm{~m}$ pixels. The analysis of DTMs altimetric accuracy indicated that DTMFg gave the worst results of the four methods analyzed. That product was classified only at the scale of 1:5,000 Class B and demonstrated an accuracy of $0.86 \mathrm{~m}$ following Vieira and Genro (2013). It demonstrated, as it did in the model with 0.4 m pixels, a non-normality, but then without bias. The GridSurfaceCreate interpolation method did not yield good results in terms of the 0.4 and $1 \mathrm{~m}$ pixels and generated inferior results when compared to the others.

Table 4: Syntheses of the analyses of Digital Terrain Models (DTMs) derived from LiDAR point clouds with $1 \mathrm{~m}$ pixels based on the PEC and the methodology proposed by Santos et al. (2016) and Vieira and Genro (2013), in Sector "A" of the Tijuca National Park, RJ, Brazil. $\Delta \mathrm{H}=$ difference between the points established using the Total Station and their homologs in absolute values.

\begin{tabular}{|c|c|c|c|c|c|c|}
\hline \multirow{2}{*}{$\begin{array}{l}\text { Method/ } \\
\text { Software }\end{array}$} & \multicolumn{2}{|c|}{$\begin{array}{l}\text { Decree N0. } \\
89.817 / 1984\end{array}$} & \multirow{2}{*}{$\Delta \mathrm{H}$} & \multicolumn{2}{|c|}{$\begin{array}{c}\text { GEOPEC (SANTOS et al., } \\
2016 \text { ) }\end{array}$} & \multirow{2}{*}{$\begin{array}{l}\text { Vieira and Genro } \\
(2013) \\
\text { Analogous to } \\
\text { PEC }\end{array}$} \\
\hline & $90 \%$ & EP & & $\begin{array}{l}\text { PEC-PCD } \\
\text { ET-CQDG }\end{array}$ & $\begin{array}{c}\text { Bias analysis } \\
\mathrm{ttab}=1.65\end{array}$ & \\
\hline \multirow[b]{2}{*}{ DTMFt } & 0.604 & 0.206 & \multirow{2}{*}{$\begin{array}{c}\text { Min: } 0.002 \\
\text { Mean: } 0.034 \\
\text { Max: } 0.991\end{array}$} & \multirow[b]{2}{*}{$\begin{array}{l}1: 2,000 \\
\text { Class D }\end{array}$} & \multirow[b]{2}{*}{$\mathrm{t} \mathrm{calc}(\mathrm{h})=1.25$} & \multirow[b]{2}{*}{$\begin{array}{c}0.63 \\
1: 2,000 \text { Class C }\end{array}$} \\
\hline & \multicolumn{2}{|c|}{$\begin{array}{l}1: 2,000 \\
\text { Class C }\end{array}$} & & & & \\
\hline \multirow[b]{2}{*}{ DTMFg } & 0.762 & 0.272 & \multirow{2}{*}{$\begin{array}{c}\text { Min: } 0.001 \\
\text { Mean }-0.001 \\
\text { Max: } 1.368\end{array}$} & \multirow[b]{2}{*}{$\begin{array}{l}1: 5,000 \\
\text { Class B }\end{array}$} & \multirow[b]{2}{*}{$*_{\mathrm{t}} \mathrm{calc}(\mathrm{h})=0.03$} & \multirow[b]{2}{*}{$\begin{array}{c}0.86 \\
1: 5,000 \text { Class A }\end{array}$} \\
\hline & \multicolumn{2}{|c|}{$\begin{array}{l}1: 5,000 \\
\text { Class A }\end{array}$} & & & & \\
\hline \multirow[b]{2}{*}{ DTMAt } & 0.526 & 0.196 & \multirow{2}{*}{$\begin{array}{c}\text { Min: } 0.0 \\
\text { Mean: } 0.065 \\
\text { Max: } 0.922\end{array}$} & \multirow[b]{2}{*}{$\begin{array}{l}1: 2,000 \\
\text { Class C }\end{array}$} & \multirow[b]{2}{*}{$\mathrm{t}$ calc $(\mathrm{h})=2.54$} & \multirow[b]{2}{*}{$\begin{array}{c}0.60 \\
1: 2,000 \text { Class B }\end{array}$} \\
\hline & \multicolumn{2}{|c|}{$\begin{array}{l}1: 2,000 \\
\text { Class B }\end{array}$} & & & & \\
\hline \multirow[b]{2}{*}{ DTMAb } & 0.575 & 0.250 & \multirow{2}{*}{$\begin{array}{c}\text { Min: } 0.001 \\
\text { Mean: } 0.061 \\
\text { Max: } 1.737\end{array}$} & \multirow[b]{2}{*}{$\begin{array}{l}1: 2,000 \\
\text { Class D }\end{array}$} & \multirow[b]{2}{*}{${ }^{*} \mathrm{tcalc}(\mathrm{h})=1.95$} & \multirow[b]{2}{*}{$\begin{array}{c}0.75 \\
1: 2,000 \text { Class C }\end{array}$} \\
\hline & \multicolumn{2}{|c|}{$\begin{array}{l}1: 2,000 \\
\text { Class B }\end{array}$} & & & & \\
\hline
\end{tabular}

*Non-normal sample. All values in meters. 
The principal discrepancy between the points determined by TS and their homologs in the models was observed in DTMAb $(1.737 \mathrm{~m})$, which also demonstrated bias. As the two models generated in ArcGis 10.3 demonstrated bias, the best result was demonstrated by DTMFt in terms of accuracy (0.604 m considering LE90, and $0.63 \mathrm{~m}$ following Vieira and Genro, 2013). As was seen in the evaluations of models using $0.4 \mathrm{~m}$ pixels, a rigorous evaluation, following Santos et al. (2016), places DTMFt in the 1:2,000 Class C scale.

Figure 4 presents the discrepancies between each of the models and the reference points determined by TS. As with the models using $0.4 \mathrm{~m}$ pixels, there is a bias with the $1 \mathrm{~m}$ models to underestimate true elevations as altimetric levels increase. That situation was most evident in DTMFg, where the mean elevational difference between DTM and the TS was $0.001 \mathrm{~m}$.

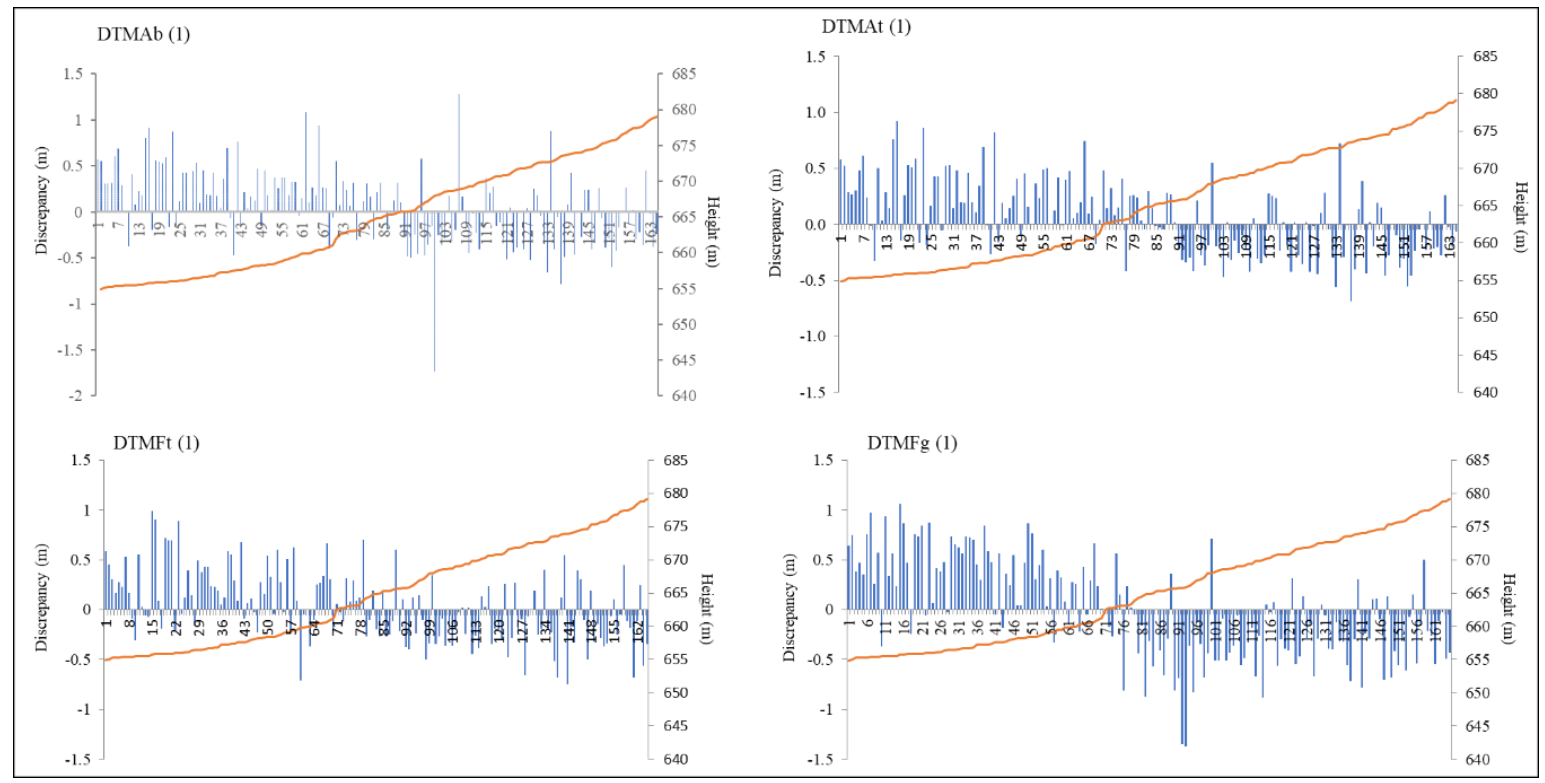

Figure 4: Graphs demonstrating the discrepancies between the points established by the Total Station and their homologs, considering a $1 \mathrm{~m}$ pixel, in Sector "A" of the Tijuca National Park, RJ, Brazil. The topographic profile of the plot is indicated by the orange line.

If the best result, however, is considered the one that does not demonstrate bias while having the greatest accuracy, considering the PEC-PCD, the best model was generated using Fusion software, with $0.4 \mathrm{~m}$ pixels, using the TINSurfaceCreate command. Figure 5 demonstrates that model applied to the total study area. 


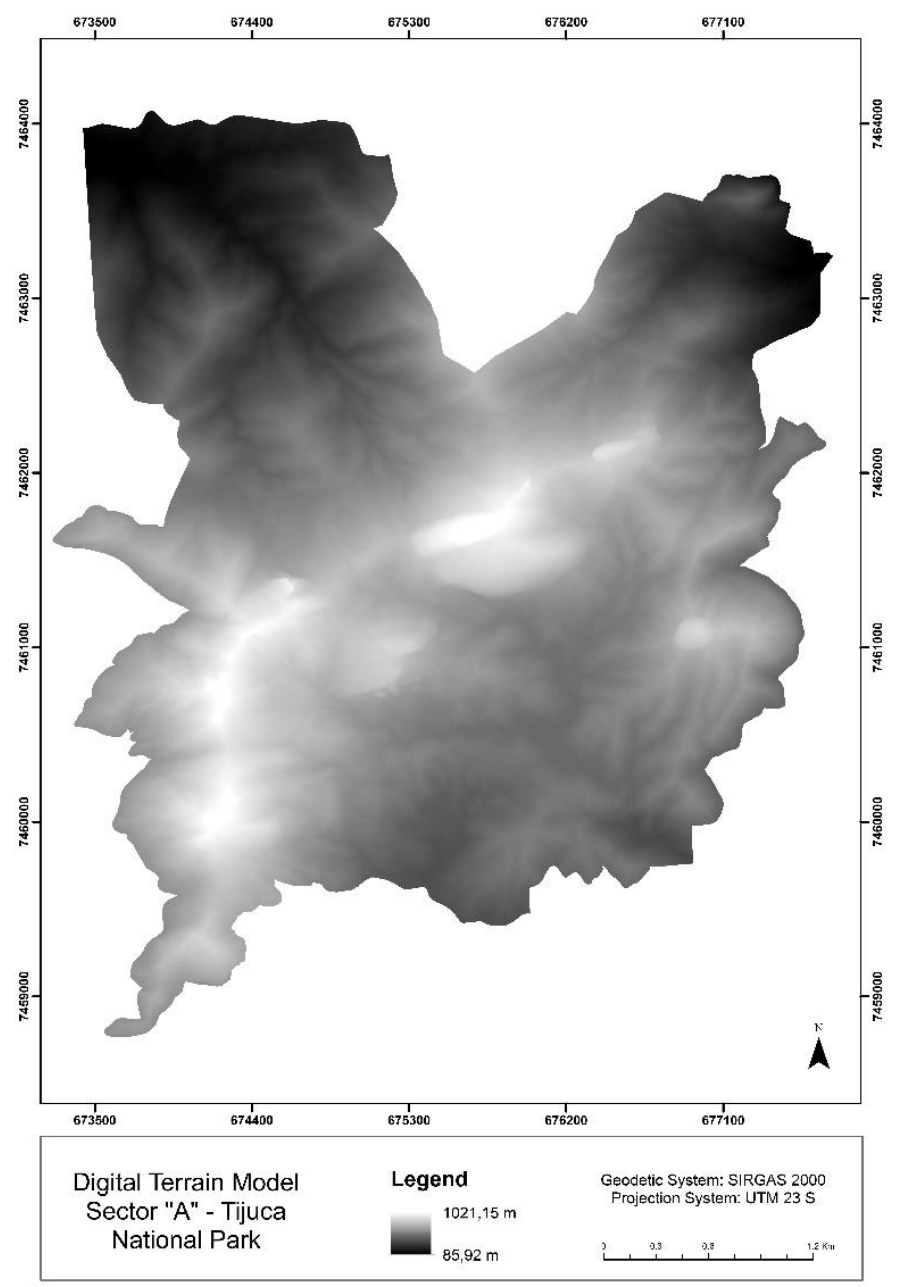

Figure 5: Digital Terrain Model of Sector "A" - Tijuca National Park, RJ, Brazil with 0.4 m pixels, produced by the interpolation of LiDAR points using Fusion software and the TINSurfaceCreate command.

The small underestimation of elevation encountered in our work was also reported by Hodgson et al. (2005). Those authors analyzed the effects of land cover and inclination in a hydrographic basin in North Carolina, USA, in an elevation model derived from LiDAR points collected during the winter (when the trees were devoid of leaves). They employed 1225 control points for six different types of land cover. The RMSE varied between 14.5 and $36.1 \mathrm{~cm}$, with the largest error being seen in the open shrub vegetation class. In relation to slope, the authors reported that there was little evidence of increasing errors with increasing declivity at low slope angles, between 0 and $10^{\circ}$, except in the low grass vegetation class, where the error increased with declivity. On the average, the model underestimated elevations independent of the vegetation cover class. Adams and Chandler (2002) likewise reported a bias of LiDAR data towards underestimating elevations, as well as a lower sensitivity to landscape inclinations when compared to DTM derived from photogrammetric surveys.

Hodgson and Breshanm (2004) reported that, in decreasing order of importance, measurements based on LiDAR systems (with GNSS or IMU equipment, for example) were 
the dominant source of errors, followed by interpolation errors, horizontal dislocation errors, and point filtration errors. The elevation of the platform holding the equipment can also influence point cloud densities, which will reflect on the accuracies of the models generated, because at higher flight altitudes there are lower quantities of photon return due to the increased diameter of the laser beam (GOODWIN et al., 2006; LEITOLD et al., 2015).

As such, in addition to forest cover, the point cloud densities of the models generated will also be a source of error, with the bias of exponential increases in errors with increasing spacing between the points (JAKUBOSKI et al., 2013), principally in tropical forests growing on areas of steep topography with dense vegetation cover (LEITOLD et al., 2016).

As discussed earlier, to evaluate the possibility of using LiDAR data in ecological research, we generated different CHMs from each of the DTMs generated. Table 5 presents the maximum, minimum, and mean values (with standard deviations) for each of the models analyzed. For comparison, the field vegetation surveys sampled 187 live individuals (representing a total density of 1870 ind./ha). The maximum tree height encountered was 32 $\mathrm{m}$, while the minimum was $2 \mathrm{~m}$; the mean tree height was $11.15 \mathrm{~m}$, with a standard deviation of $5.1 \mathrm{~m}$.

Table 5: Maximum, minimum, and mean height values (with standard deviations) of the Canopy Height Models (CHMs) generated from LiDAR data in Sector "A" of the Tijuca National Park, RJ, Brazil. CHMFt(0.4)= generated by Fusion software, TINSurfaceCreate method, with $0.4 \mathrm{~m}$ pixels; $\mathrm{CHMFg}(0,4)=$ generated by Fusion software, GridSurfaceCreate method, with $0.4 \mathrm{~m}$ pixels; $\mathrm{CHMAb}(0,4)=$ generated by ArcGis 10.3 software, Binning method, with 0.4 m pixels; CHMAt $(0,4)=$ generated by ArcGis 10.3 software, TIN method, with $0.4 \mathrm{~m}$ pixels $\mathrm{m}$; $\mathrm{CHMFt}(1)=$ generated by Fusion software, TINSurfaceCreate method, with $1 \mathrm{~m}$ pixels; CHMFg(1)= generated by Fusion software, GridSurfaceCreate method, with $1 \mathrm{~m}$ pixels m; $\mathrm{CHMAb}(1)=$ generated by ArcGis 10.3 software, Binning method, with $1 \mathrm{~m}$ pixels; CHMAt $(1)=$ generated by ArcGis 10.3 software, $T I N$ method, with $1 \mathrm{~m}$ pixels.

\begin{tabular}{|c|c|c|}
\hline & Minimum - Maximum height & Mean height and standard deviation \\
\hline CHMFt(0.4) & $0-30.40$ & $19.59 \pm 5.2$ \\
\hline CHMFg(0.4) & $0-30.95$ & $19.98 \pm 5.08$ \\
\hline CHMAb(0.4) & $0.34-29.81$ & $18.19 \pm 4.95$ \\
\hline CHMAt(0.4) & $0.34-29.81$ & $18.19 \pm 4.95$ \\
\hline CHMFt(1) & $0.01-30.41$ & $21.82 \pm 4.11$ \\
\hline CHMFg(1) & $0-30.54$ & $21.92 \pm 4.06$ \\
\hline CHMAb(1) & $0-29.63$ & $18.23 \pm 4.3$ \\
\hline CHMAt(1) & $0.36-29.79$ & $18.23 \pm 4.95$ \\
\hline
\end{tabular}

Among the models generated, the maximum tree height varied from $29.63 \mathrm{~m}$ (CHMAb(1)) to $30.95 \mathrm{~m}(\mathrm{CHMFg}(0.4))$, while in the field, the maximum height was $32 \mathrm{~m}$. That difference was very small, especially considering the difference in time of two years between the over flight and the field survey, as it is quite possible that some of the trees grew during that period. The smallest plant heights correspond to the small openings in the crown 
that allow the laser beam to arrive near ground level. The mean heights of the models vary between 18.23 and $21.92 \mathrm{~m}$, values quite different from that encountered in the field. That situation requires some consideration. A definitive height value was attributed to each individual sampled in the field, while it is each pixel that is assigned a height value in the CHM. As the model is generated based on differences between the DSM and the DTM, only the crowns of the tallest individuals are included, raising the assigned mean height. In the field survey of individuals with diameters $\geq 5 \mathrm{~cm}$ at $1.3 \mathrm{~m}$ above soil level (the inclusion criteria recommended for studies of vegetation structure in the Atlantic Forest), individuals are necessarily included whose crowns are situated below canopy and emergent individuals, thus lowering the mean height. If we consider only the 28 individuals whose crowns were totally exposed to sunlight, the mean height increases to $18.82 \mathrm{~m}$, a value remarkably close to those encountered using LiDAR data.

If data analysis were based solely on the maximum and mean heights encountered, it could be argued that the DTMs generated from the different interpolation methods were very similar within the study area. However, when the model data are analyzed in terms of height classes, some differences appear, principally as a function of the software utilized.

In the models generated using ArcGis 10.3 software with $0.4 \mathrm{~m}$ pixels, there were no variations in the percentages of pixels in each of the sampled classes (Figure 5). The greatest concentration of pixels was seen in the $15.1-20 \mathrm{~m} \mathrm{(35.1 \% )}$ and $20.1-25 \mathrm{~m}(33.7 \%)$ classes; pixels above $25 \mathrm{~m}$ represented only $5.6 \%$ of the sample. It must be remembered that the DTMs generated using that software demonstrated very similar accuracies in both of the methodologies tested: $0.57 \mathrm{~m}$ (DTMAt) and $0.58 \mathrm{~m}$ (DTMAb). In spite the fact that the differences between the interpolations were small in some of the models generated using Fusion software, that difference was almost $17 \%$ in the $10.1-15 \mathrm{~m}$ class; with $12.5 \%$ of the pixels in that class in $\mathrm{CHMFg}$, and $29.1 \%$ in CHMFt. It is important to remember that the DTMFg model demonstrated the least accuracy, in addition to bias in the data, which were probably reflected in the differences between those two models. 


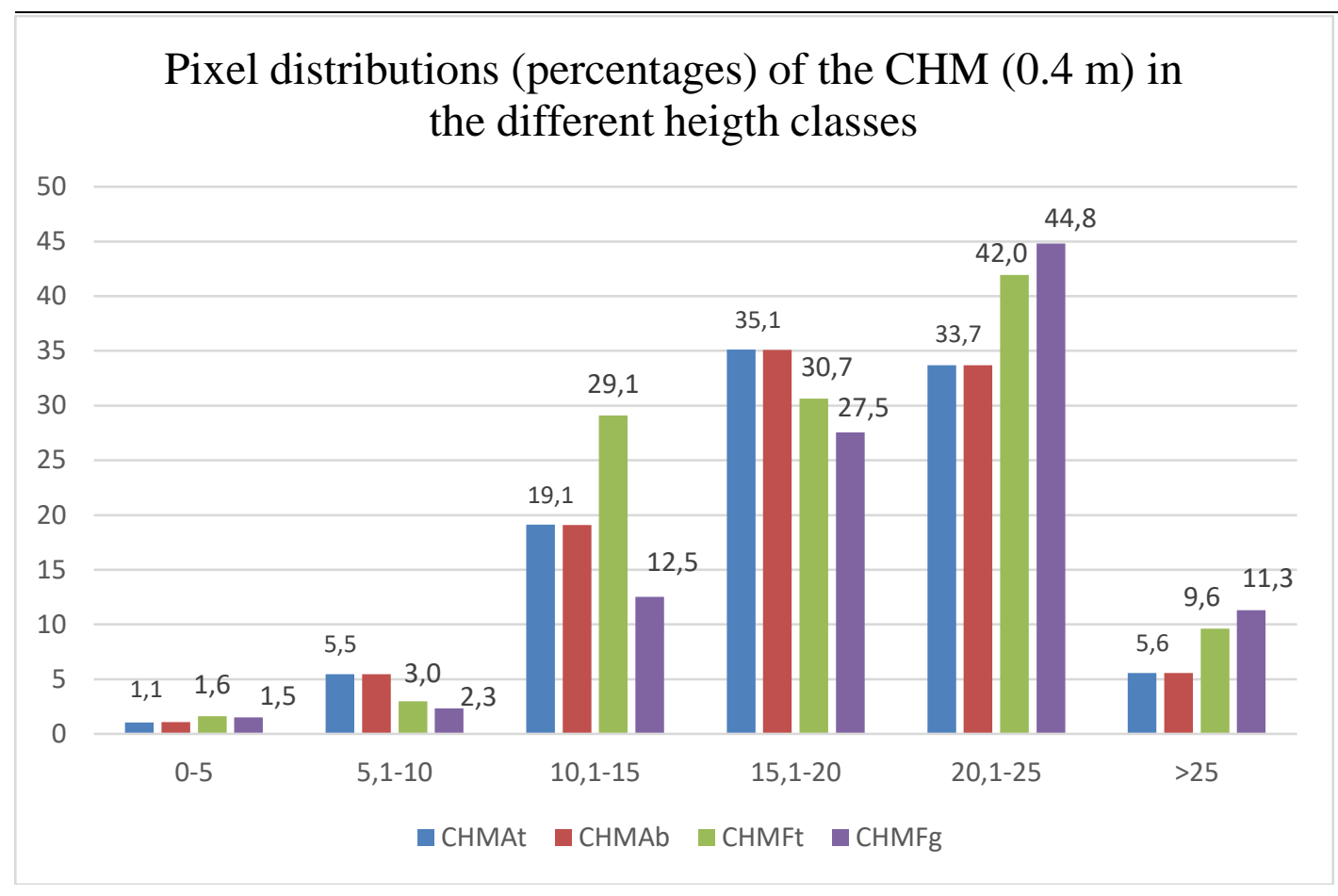

Figure 5: Pixel distributions in the different height classes in the different Canopy Height Models (CHMs) with resolutions of $0.4 \mathrm{~m}$ in Sector "A" of the Tijuca National Park, RJ, Brazil.

In the models with $1 \mathrm{~m}$ pixels (Figure 6), the differences between the softwares were more visible. In the CHM generated using ArcGis 10.3 software, the greatest pixel concentration was in the $15.1-20$ m class, while in the CHMs generated using Fusion software, the greatest pixel concentration was in the $20.1-25 \mathrm{~m}$ class. On the other hand, the differences between the Fusion interpolators and those of ArcGis 10.3 in those models were almost non-existent and a small difference between the results was only seen in the $>25$ m class. 


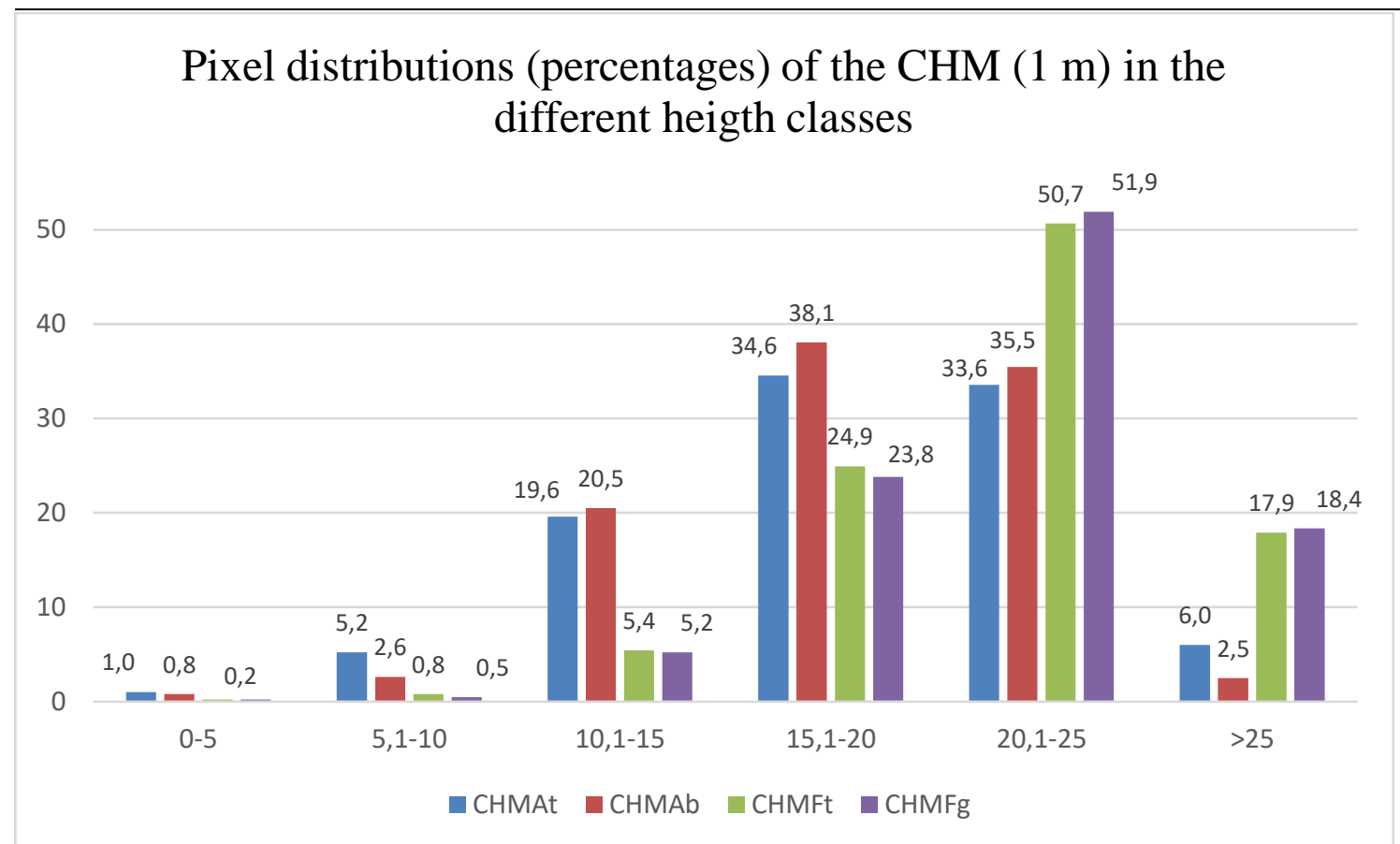

Figure 6: Pixel Distribution in the different height classes in the Canopy Height Models (CHMs) with $1 \mathrm{~m}$ resolutions in Sector "A" in the Tijuca National Park, RJ, Brazil.

That evaluation affirmed the view of Leitold et al. (2016) that it was possible to use LiDAR data to quantify the stocks and dynamics of aboveground biomass. The quality of the results, however, will be directly related to the choice of an accurate and precise DTM, especially in environments with heavy forest cover.

\section{Conclusion}

The use of LiDAR data to generate high accuracy DTM is very promising, principally in areas with dense vegetation cover, as the dense point cloud resulting from the laser pulse is able to penetrate to the forest floor through small openings in the canopy.

The results presented here, on the other hand, stressed the importance of studies that can determine the accuracies of the models generated. There are currently innumerable programs capable of reading .las archives, including both commercial and open source softwares. Fusion software, developed by the U.S. Forest Service of the Department of Agriculture, has been found to be quite efficient at generating DTM using the TINSurfaceCreate command and gave the best results in terms of generating a product with high accuracy and without bias. The functioning of both interpolation methods was very similar using ArcGis 10.3. It was found that smaller pixel sizes tended to underestimate tree heights as compared to data generated with the Total Station.

Estimates of maximum tree heights using LiDAR were very similar to those found through direct measurements in the field, although significant differences were observed in terms of height classes, principally between softwares. That result emphasizes the importance of performing surveys with high point densities, principally in tropical environments with complex topographies; the higher costs of those surveys will be compensated by the excellent results of using that technology to generate DTM and consequently, CHM. 


\section{Acknowledgements}

We thank the Chico Mendes Institute of Biodiversity (ICMBio) for working permits; the Pereira Passos Institute (IPP), HANSA L.t.d.a. and Dr. Andre Avelar for Lidar data cession; J. Caruzo, R. Rangel, E. Lacerda and Mensurar for field and technical assistance and CAPES for Phd scholarship.

\section{References}

ADAMS, J.C., CHANDLER, J.H. Evaluation of LiDAR and medium scale photogrammetry for detecting soft-cliff coastal change. The Photogrammetry Record, v.17, n.99, p.405-418, 2002.

BARBOSA, L.S. Avaliação de Modelos Digitais de Terreno gerados por escaneamento a laser (LiDAR) no Maciço da Tijuca, RJ. Dissertação de Mestrado. Departamento de Geografia. Universidade Federal do Rio de Janeiro. 131 p., 2015

BARROS, R.S.; CRUZ, C.B.M; RABACO, L.M.L. \& FAGUNDES, F. de O. Avaliação da Exatidão Planialtimétrica de produtos oriundos de Radar Interferométrico e LiDAR em área coberta por floresta. In: Anais... XVI Simpósio Brasileiro de Sensoriamento Remoto, Foz do Iguaçu, PR, INPE, p. 2126-2133, 2013

BECKER, J.H. \& CENTENO, J.A.S. Avaliação de métodos de filtragem de nuvens de pontos derivados do sistema laser scanner aerotransportado para obtenção de MDT. Revista Brasileira de Cartografia, v. 65, n. 4, p. 651-659, 2013.

BERGEN, S. J., GOETZ, R. O., DUBAYAH, G. M,. HENEBRY, C. T., HUNSAKER, M. L., IMHOFF, R. F., NELSON, G. G., PARKER, \& V. C. RADELOFF. Remote sensing of vegetation 3-D structure for biodiversity and habitat: Review and implications for lidar and radar spaceborne missions. Journal of Geophysical Research. V.114, p. 1-13, 2009.

BRASIL. Decreto-lei $\mathbf{n}^{\mathbf{0}} \mathbf{8 9 . 8 1 7}$ de 20 de junho de 1984. Estabelece as Instruções Reguladoras das Normas Técnicas da Cartografia Nacional. Disponível em $<$ http://www.planalto.gov.br/ccivil_03/decreto/1980-1989/D89817.htm>. Acesso em 02 julho 2017.

CLARK, M.L.; CLARK, D.B., ROBERTS, D.A. Small-footprint lidar estimation of subcanopy elevation and tree height in a tropical rain forest landscape. Remote Sensing of Environment, v.91, p.69-89, 2004.

COLEHO-NETTO, A.L. Surface hidrology and soil erosion in a tropical montainous rainforest drainage basin, RJ, Phd thesis, Katholieke Univ. Leuven, Belgiun, 181 p., 1985.

COELHO-NETTO, A.L. A interface florestal-urbana e os desastres naturais relacionados à água no Maciço da Tijuca: desafios ao planejamento urbano numa perspectiva sócioambiental. Revista do Departamento de Geografia, v.16, p.46-60, 2005.

COELHO-NETTO, A.L.; AVELAR, A.S.; FERNANDES, M.C. \& LACERDA, W.A. Landslide susceptibility in a mountainous geoecosystem, Tijuca Massif, Rio de Janeiro: The role of morphometric subdivision of the terrain. Geomorphology, v.87, p.120-131, 2007. 
CONGALTON, R.G.; GREEN, K. Assessing the accuracy of remotely sensed data: principles and practices. Positional Accuracy. 2. Ed. Boca Raton, Florida, cap.3, p. 19-53, 2009.

CRUZ, C.B.M.; BARROS, R.S.; CARDOSO, P.V.; REIS, R.B.; ROSARIO, L.S.; BARBOSA, S.S.; RABACO, L.M.L.; LOURENÇO, J.S.Q. Avaliação da exatidão planimétrica dos modelos digitais de superfície (MDS) e do terreno (MDT) obtidos através do LiDAR. In: Anais... XV Simpósio Brasileiro de Sensoriamento Remoto, Curitiba, PR, INPE, p. 5463-5470, 2011.

DIAS, M.A., COELHO-NETTO, A.L. Distribuição de manchas de gramínea em um fragmento de floresta Atlântica urbano montanhosa - Maciço da Tijuca, RJ. Revista de Geografia, v.especial VIII SINAGEO, n.2, p.148-164, 2011.

GORGENS, E.B.; SILVA, A.G.P.; RODRIGUEZ, L.C.E. Lidar: aplicações florestais. 1 Ed., Curitiba, PR. CRV, 2014.

GOODWIN, N.R.; COOPS, N.C.; CULVENOR, D.S. Assessment of forest structure with airbone LiDAR and the effects of platform altitude. Remote Sensing of Environment, v.103, p.140-152, 2006.

HODGSON, M. E.; JENSEN, J.; RABER, G.; TULLIS, J.; DAVIS, B. A.; THOMPSON, G.; SCHUCKMAN, K. Evaluation of lidar-derived elevation and terrain slope in leaf-off conditions. Photogrammetric Engineering and Remote Sensing, v. 71, n. 7, p. 817-823, 2005.

HODGSON, M. E.; BRESNAHAN, P. Accuracy of airborne LiDAR-derived elevation: empirical assessment and error budget. Photogrammetric Engineering and Remote Sensing, v. 70, n. 3, p. 331-339, 2004.

ICMBIO. 2008. Plano de manejo. Parque Nacional da Tijuca. Disponível em <http:// www.icmbio.gov.br/portal/images/stories/docs-planos-de-manejo/parna_tijuca_pm.pdf >. Acesso em 20 de novembro de 2016.

INSTITUTO BRASILEIRO DE GEOGRAFIA E ESTATÍSTICA. Manual Técnico da Vegetação Brasileira. Série: Manuais Técnicos em Geociências. $2^{\mathrm{a}}$ ed. Rio de Janeiro: IBGE, 2012.

.Resolução do Presidente número 1/2015. Disponível em http://geoftp.ibge.gov.br/metodos_e_outros_documentos_de_referencia/normas/rpr_01_25f ev2005.pdf. Acesso em 24 de abril de 2020.

JAKUBOWSKI, M. K.; GUO, Q.; KELLY M. Tradeoffs between lidar pulse density and forest measurement accuracy. Remote Sensing of Environment, v. 130, p. 245-253, 2013

LEITOLD, V.; KELLER, M.; MORTON, D.C., SHIMABUKURO, Y.E. Landscape-scale variation in forest structure and biomass along an elevation gradient in the Atlantic Forest of the Serra do Mar, Brazil. In: Anais... XVII Simpósio Brasileiro de Sensoriamento Remoto, João Pessoa, p. 1192-1199, 2015.

LEITOLD, V.; KELlER, M.; MORTON, D.C.; COOK, B.D.; SHIMABUKURO, Y.E. Airborne lidar-based estimates of tropical forest structure in complex terrain: opportunities and trade-offs for REDD+. Carbon balance and management, v. 10, n. 1, p. 3, 2015. (a)

LIM, K.; TREITZ, P.; WULDER, M.; ST-ONGE, B. \& FLOOD, M. LiDAR remote sensing 
of forest structure. Progress in Physical Geography, v. 27, n.1, P.88-106, 2003.

LIU, X. Airbone LiDAR for DEM generation: some critical issues. Progress in Physical Geography, v. 32, n.1, p. 31-49, 2008.

MCGAUGHEY, R. J. FUSION manual, version 2.90. USDA Forest Service, 2016.

OLIVEIRA, R.R. ZAÚ, A.S.; LIMA, D.F; SILVA, M.B.R., VIANNA, M.C. Dinâmica ecológica de encostas no Maciço da Tijuca - RJ. Oecologia Brasiliensis v.1, p. 523-541, 1995.

REUTEBUCH, S. E.; McGAUGHEY, R. J.; ANDERSON, H. E.; CARSON, W. W. Accuracy of a high-resolution lidar terrain model under a conifer forest canopy. Canadian Journal of Remote Sensing, v. 29, n. 5, p. 527-535, 2003.

SANTOS, A.P.; RODRIGUES, D.D.; SANTOS, N.T.; JUNIOR, J.G. Avaliação da acurácia posicional em dados espaciais utilizando técnicas de estatística espacial: proposta de método e exemplo utilizando a norma brasileira. Boletim de Ciências Geodésicas, v.22, n.4, p.630650, 2016. Disponível em http://dx.doi.org/10.1590/S1982-21702016000400036. Acesso em 28 de maio de 2018.

SCHIMALLESKY, V., CENTENO, J.A.S. Avaliação da qualidade da avaliação altimetrica derivada da varredura a laser em uma região coberta por vegetação - estudo de caso. Floresta, v. 38, n. 4, p. 597-606, 2008.

VIEIRA, H. B. G. \& GENRO, R. S. Inferência estatística para validação de documentos cartográficos obtidos com sensores remotos orbitais ou aerotransportados, em áreas de operação da Petrobras. In: Anais...XV Simpósio Brasileiro de Sensoriamento Remoto, Curitiba, PR. INPE, p.2339-2346, 2011. 